\title{
How Do You Build Great Practice Culture?
}

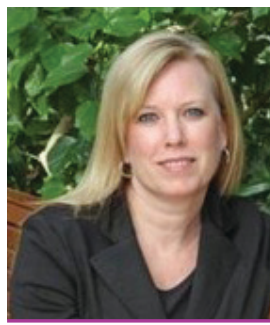

Trudi Charest, Ro

Trudi Charest is the Co-Founder of Marketing4ECPs, a digital marketing agency for optometrists. Trudi can be reached at trudi@4ecps.com or www.marketing4ecps.com.

$\mathrm{C}$ ompany culture is a term often used when candidates are asking questions of a prospective employer about the business. They're asking about work/ life balance, core values, atmosphere and team work. What would you say if someone asked you this question? Some practice owners work hard at office culture, knowing it has numerous residual benefits from employee retention to increased productivity and happier patients. These are often the most successful and thriving practices we see. Great workplace = great profits! So how do you make great culture happen in your practice?

Building office culture takes effort and time. You don't need huge budgets or have to offer all the perks of big businesses like Zappos (who are known for amazing culture), but you can take lessons from some of their initiatives and start a culture drive in your office.

9 STEPS TO BUILDING GREAT PRACTICE CULTURE:

1. Mission statement \& core values

Ensure you have an updated mission statement and core values. Having them can help you align business decisions and initiatives that are right for the practice. Choose three to five core values. Example: Integrity, Passion, Support and Teamwork.

2. Involve the team

The more you involve the team in all the important practice decisions, the more likely they will be adopted and embraced. Staff want to feel like they play a part in developing the culture and atmosphere.

3. Assess what works and what needs improvement

Plan a two-hour staff meeting centered on understanding what works well in the practice, from office processes to team building. Be open to hearing the good and the bad. In this meeting, ensure the team works on solutions and goals towards a better environment, work operations and culture.

4. Establish a committee

Don't feel like this is only a practice owner activity. Assign one or two people from the office to head up a "Culture Committee". Give them a budget and guidelines for ways to build culture and meet with them monthly to determine progress and next steps.

\section{Invest some time}

Creating a great culture is not a one instance event. This is an ongoing effort and continual plan of looking at ways to make your practice a great place to work. A great place to have an eye exam. A place everyone from staff, to suppliers to patients want to be at.

\section{Plan team events}

Part of building culture includes encouraging your team to bond. We work in busy, hectic environments that don't tend to allow time for a lot of team building. Plan offsite events such as industry conferences, staff retreats or a fun activity to allow the team some time together away from the office. 


\section{Celebrate}

Take the opportunity to celebrate wins - even small ones. It could be a great patient testimonial, or a goal reached or exceeded. It could be a staff member's personal achievement. When the practice is doing well and experiencing wins, the staff will feel like they are impacting the business.

\section{Hire right - fire right}

Now that you know culture is an important aspect of a successful optometry practice, you must continue to make decisions that reflect your core values. That includes hiring and firing. When you hire the right people for your practice, it can truly change the trajectory of the business. But the same thing can happen when you hire the wrong people. Work hard to recruit good staff and don't retain staff that aren't in keeping with the practice culture.

\section{Measure}

Conduct employee and patient satisfaction surveys to ensure you are moving in the right direction. When employees and patients are happy, the culture is positive.

Last note ... office culture is not just about work/ life balance. It is a commitment to each other and to supporting the type of business you all want to work in. It is building an amazing environment and atmosphere and holding each other accountable to keeping it that way. 